Vol. 51, n. 5 : pp.911-916, September-October 2008 ISSN 1516-8913 Printed in Brazil
BRAZILIAN ARCHIVES OF BIOLOGY AND TECHNOLOGY

AN INTERNATIONAL JOURNAL

\title{
Morphological Markers for Microspore Developmental Stage in Maize
}

\author{
Ana Paula de Moraes ${ }^{1}$, Fernanda Bered ${ }^{1}$, Fernando Irajá Felix de Carvalho $^{2}$ and Eliane \\ Kaltchuk-Santos ${ }^{1}$ * \\ ${ }^{1}$ Departamento de Genética; Universidade Federal do Rio Grande do Sul; Av. Bento Gonçalves, 9500; prédio \\ 43323; C.P.: 15053; eliane.kaltchuk@ufrgs.br; 91501-970; Porto Alegre - RS - Brasil. ${ }^{2}$ Departamento de \\ Fitotecnia; Universidade Federal de Pelotas; Pelotas - RS - Brasil
}

\begin{abstract}
The use of maize in anther culture has been limited because only few genotypes presented a high androgenetic potential. Obtaining the proper stage of microspore development at culture initiation is one of the most crucial factors for success in the androgenesis. For Brazilian maize genotypes there are no studies reporting a correlation between cytological features and morphological parameters. In this study, morphological parameters were recorded and associated with cytological specific stages of the the microsporogenesis in two Brazilian maize genotypes that were sowed in different places (field and growing chamber). For both genotypes, the plants of the growing chamber presented a delay in development. Spikelets length and anther length/spikelet length ratio are not good parameters since they can be greatly influenced by the environment. The anther length was the more reliable parameter to correlate with a specific developmental stage. Nevertheless, variations between genotypes and environment were detected.
\end{abstract}

Key words: Androgenesis, anther culture, microsporogenesis, Zea mays

\section{INTRODUCTION}

The gametophyte of the flowering plants can switch its development towards a sporophytic route, giving rise to an haploid plant. This phenomenon, known as androgenesis, have permitted through anther culture, speeds up the breeding cycle, increases the selection efficiency, and results in a double haploid population, which can be useful for the mapping of qualitative and quantitative traits (Afza et al., 2000; Murigneux et al., 1994). The haploid plants induction is still limited in some crops due to many factors which influence the efficiency of the culture. One of the most crucial factors for the success is to obtain the proper stage of microspore development at the culture initiation. For many crops, the stage near to the first mitosis has been considered the most inductive (Peters et al., 1999). Secale cereale (Wang et al., 2000) and Brassica oleraceae (Kameya and Hinata, 1970) are exceptions in which the pollen grains must be with the starch deposition and Arabidopsis thaliana (Gresshoft and Doy, 1972) and Lycopersicon escutelum (Brasileiro et al., 1999) that must be at meiosis. For cereals the optimal developmental stages are mid to late uninucleate, in barley and wheat, and late uninucleated and early binucleated for rice and maize (Jähne and Lörz, 1995).

Although the growth conditions influence the morphology of the donor plants, it is possible to correlate the stages of the microspore development

\footnotetext{
* Author for correspondence
} 
with other morphometric attributes of the plant. For dicots, as soybean, the bud length was correlated with microspore stage (Lauxen et al., 2003). For monocots, parameters such as interligule length between the flag leaf and second leaf, thickness of the tiller or spike and anther length have been associated with developmental stages (Jähne and Lörz, 1995; Chang and Neuffer, 1989). Maize anther culture dates back to 1974 (Ku et al., 1978). Since then, notable progress has been made in this field, especially by the new knowledge about nutrient requirements, pretreatments and selection of responsive genotypes (Petrova et al., 1993). However, for Brazilian genotypes, nothing has been done in maize anther culture.

In order to establish similar information for the anther culture of Brazilian maize genotypes, a detailed analyses was made between the microspore developmental stages and the morphological traits of the plant in two genotypes grown at two different conditions.

\section{MATERIALS AND METHODS}

The genotypes AS 3601 and Pioneer 3063 were sowed in the field and in a growing chamber, under $16-\mathrm{h}$ photoperiod at $24-26^{\circ} \mathrm{C}$ for 30 days and $26-28^{\circ} \mathrm{C}$ until the collection stage. The tassels of three plants of each genotype were harvested. In both genotypes, the tassels were always collected before the emergence of the leaf whorl (probable period in which anthers presented meiosis or immature pollen grains). The plant age (days after sowing) and number of plant leaves were determined at the tassels collection time.

From each tassel, thirty spikelets samples distributed in different position of the tassel were collected and measured. The major anther of each spikelet was measured, too. The three bigger anthers from each spikelet were fixed in 3:1 (ethanol: acetic acid) at room temperature for $24 \mathrm{~h}$ and stored at $-20^{\circ} \mathrm{C}$ before analysis. At the time of analysis, the anthers were squashed in propionic carmine $6 \%$ on glass slides and sealed under cover slips with bee's wax. The microspores were staged and classified under a Zeiss Axioplan Universal photomicroscope. For recording purposes, the observed developmental phases were grouped into three classes of cytological examinations: 1meiosis, 2- early uninucleated microspore, 3- late uninucleated microspore until early binucleated pollen. Three spikelets per tassel were selected to represent each cytological stage and its morphological traits were measured. The measurements included: spikelet size, anther size and the anther length/spikelet length ratio. The data was analyzed in the SPSS 10.0 statistical software and the Nonparametric Kruskal-Wallis test was performed for genotypes and growth place differentiation, followed by a Dunn test. For the spikelet measure, anther measure, anther/spikelet relationship and microspore developmental stage for each genotype, at each growth place, the ANOVA test was performed followed by a Student-Newman-Keuls multiple range test.

\section{RESULTS AND DISCUSSION}

\section{Plant age and leaf number}

The genotypes cultivated in the field presented a similar pattern of development with almost the same plant age and leaf number (Table 1). However, plants of both genotypes sowed in the growing chamber presented a delay in the development since the plants age was much more advanced and the number of leaves was higher at the phase determined as the pattern for the collection of the tassels. In the growing chamber, the genotype AS 3601 was more delayed in the development than the Pioneer 3063 (95 days and 75 days, respectively).

The observed microspore developmental stages in this work are represented in Figure 1. At the collection time, the tassels of genotype AS 3601 presented anthers containing pollen-mother-cells (PMC's) at the meiosis and uninucleated microspores at both sowing places. On the other hand, the tassels of the Pioneer 3063 at the growing chamber were delayed, presenting PMC's at meiosis while the same genotype in the field had microspores uni and binucleated.

In other studies, similar results were observed. Rodríguez et al. (1998) observed noticeable differences in the morphology and phenology between the two cultivar tested. While one cultivar had three to seven leaves fully exposed after 30-50 days after sowing, the other one had eight to ten leaves. The same happened in relation to cytological stage, while one cultivar had uninucleated microspores after 30-50 days after sowing, another cultivar presented them only after 65-75 days. 


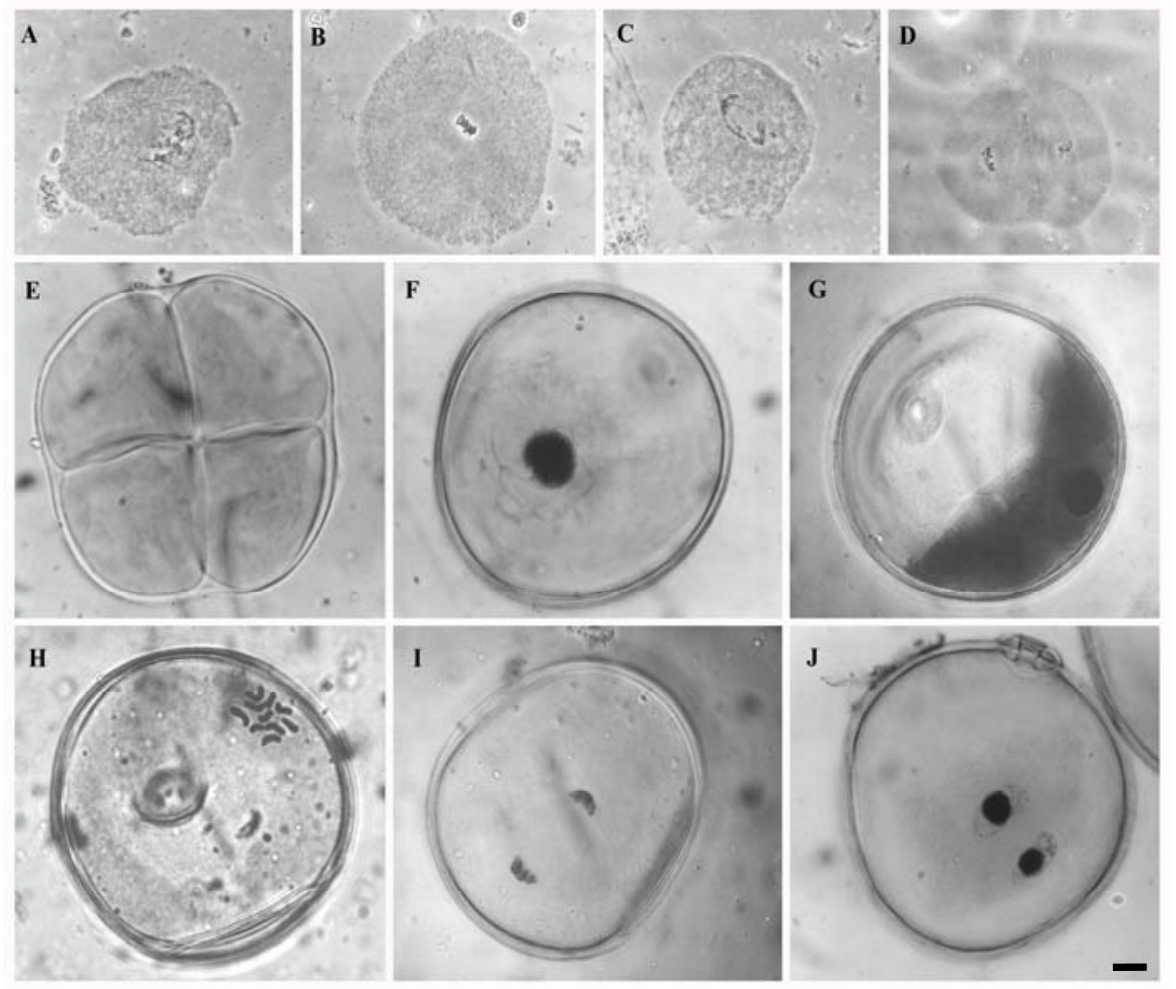

Figure 1 - Pollen grain development in maize: microsporogenesis (A-E) and microgametogenesis (F-J). A) Prophase, B) Metaphase I, C) Anaphase I, D) Metaphase II, E) Tetrad, F) Early microspore, G) Vacuolated microspore, H) First Microspore mitosis (metaphase), I) Microspore anaphase, J) Binucleated pollen grain. Bar: $10 \mu \mathrm{m}$.

Table 1 - Mean of plant age, number of leaves and stage of development observed in two Brazilian maize genotypes before leaf whorl tassels emergency.

\begin{tabular}{ccccccc}
\hline \multirow{2}{*}{ Genotypes } & \multicolumn{2}{c}{$\begin{array}{c}\text { Mean of plant age } \\
\text { (days) }\end{array}$} & \multicolumn{2}{c}{$\begin{array}{c}\text { Mean of leaf } \\
\text { number }\end{array}$} & \multicolumn{2}{c}{$\begin{array}{c}\text { Interval of microspore developmental } \\
\text { stages observed }\end{array}$} \\
\cline { 2 - 7 } & Field & $\begin{array}{c}\text { Growing } \\
\text { chamber }\end{array}$ & Field & $\begin{array}{c}\text { Growing } \\
\text { chamber }\end{array}$ & Field & Growing chamber \\
\hline AS 3601 & 57 & 95 & 15 & 21 & $\begin{array}{c}\text { Meiosis - } \\
\text { uninucleated }\end{array}$ & $\begin{array}{c}\text { Meiosis - } \\
\text { uninucleated } \\
\text { Pioneer 3063 }\end{array}$ \\
56 & 75 & 13 & 16 & Uni - Binucleated & $\begin{array}{c}\text { Meiosis - early } \\
\text { binucleated }\end{array}$ \\
\hline
\end{tabular}


Table 2 - Average of spikelet length, anther length and anther/spikelet length (A/S) ratio of two analyzed genotypes, AS 3601 and Pioneer 3063, grown in the field and in growing chamber.

\begin{tabular}{|c|c|c|c|c|c|}
\hline \multirow{2}{*}{ Genotype } & \multirow{2}{*}{ Environment } & \multirow{2}{*}{$\begin{array}{c}\text { Microspore developmental } \\
\text { stage }\end{array}$} & \multicolumn{3}{|c|}{ Characteristics average } \\
\hline & & & $\begin{array}{c}\text { Spikelet } \\
\text { length }(\mathrm{CV} \%)\end{array}$ & $\begin{array}{l}\text { Anther length } \\
\text { (CV\%) }\end{array}$ & $\begin{array}{l}\text { A/S ratio } \\
(\mathrm{CV} \%)\end{array}$ \\
\hline AS 3601 & Field & Meiosis & $5.24 \mathrm{a}(21.9)$ & $2.63 a(15.4)$ & $0.50 \mathrm{a}(18.1)$ \\
\hline AS 3601 & Field & Early uninucleated & $7.16 \mathrm{~b}(7.4)$ & $3.14 b(10)$ & $0.44 \mathrm{~b}(8.8)$ \\
\hline AS 3601 & Field & $\begin{array}{l}\text { Late uninucleated-early } \\
\text { binucleated }\end{array}$ & $7.31 b(15.5)$ & $3.16 b(11.1)$ & $0.43 b(11.7)$ \\
\hline Pioneer 3063 & Field & Early uninucleated & $6.09 \mathrm{a}(9.9)$ & 2.91a (10.5) & $0.48 \mathrm{a}(7.6)$ \\
\hline Pioneer 3063 & Field & $\begin{array}{l}\text { Late uninucleated-early } \\
\text { binucleated }\end{array}$ & $7.32 \mathrm{~b}(7.0)$ & $3.47 \mathrm{~b}(7.2)$ & $0.48 \mathrm{a}(6.4)$ \\
\hline AS 3601 & $\begin{array}{l}\text { Growing } \\
\text { chamber }\end{array}$ & Meiosis & $4.46 a(26.4)$ & $1.48 \mathrm{a}(24.7)$ & $0.35 \mathrm{a}(24.3)$ \\
\hline AS 3601 & $\begin{array}{l}\text { Growing } \\
\text { chamber }\end{array}$ & Early uninucleated & $6.08 \mathrm{~b}(21.5)$ & $2.28 b(14.3)$ & $\begin{array}{c}0.41 \mathrm{ab} \\
(28.0)\end{array}$ \\
\hline AS 3601 & $\begin{array}{l}\text { Growing } \\
\text { chamber }\end{array}$ & $\begin{array}{l}\text { Late uninucleated-early } \\
\text { binucleated }\end{array}$ & $6.57 b(11.5)$ & $2.50 \mathrm{~b}(8.5)$ & $0.41 \mathrm{ab}(9.2)$ \\
\hline Pioneer 3063 & $\begin{array}{l}\text { Growing } \\
\text { chamber }\end{array}$ & Meiosis & $5.70 \mathrm{a}(15.2)$ & $2.05 \mathrm{a}(13)$ & $0.36 \mathrm{a}(13.7)$ \\
\hline Pioneer 3063 & $\begin{array}{l}\text { Growing } \\
\text { chamber }\end{array}$ & Early uninucleated & $6.84 a(15.3)$ & $2.37 b(18.8)$ & $0.35 \mathrm{a}(16.2)$ \\
\hline Pioneer 3063 & $\begin{array}{l}\text { Growing } \\
\text { chamber }\end{array}$ & $\begin{array}{c}\text { Late uninucleated-early } \\
\text { binucleated }\end{array}$ & 7.36a $(8.5)$ & $2.92 b(11.7)$ & $0.34 \mathrm{a}(7.6)$ \\
\hline
\end{tabular}

Average followed by the same letter in column did not differ from other in the same genotype and environment. CV\% represents the coefficient of variation, in percentage, in each sample.

\section{Tassel morphological comparison}

During maize development, morphological characteristics of a plant can vary greatly according to the environment and the genotype. The variations are present also between plants of the same genotype (Chang and Neuffer, 1989). The present results showed that the traits evaluated and measured varied significantly depending on the environment and the genotype tested. The analysis of the morphological characteristics was made separately for genotype and environment (Table 2).

The data showed that the spikelets length is a parameter that can be greatly influenced by the environment. In some conditions, the spikelet length showed variations among the stages, but in others, it did not. This was clearly observed in the genotype Pioneer 3063 (field $\mathrm{x}$ growing chamber) The anther length/spikelet length ratio (A/S ratio) was also not a good parameter. The ratios did not vary significantly among the stages of early uninucleated to late binucleated. However, it was very important to establish an adequate correlation between the morphological parameter and cytological phase since some stages were not responsive in the maize anther culture, like the late binucleated pollen grain (Jähne and Lörz, 1995). In the present study the morphological parameter that best reflected the cytological stage of the microsporogenesis was the anther length. This parameter permitted to select adequately anthers containing uninucleated to early-binucleated pollen grains which were those that could switch the development pathway for a sporophytic route. 
In rye also, the anther length was considered an appropriate morphological marker for assessed specific developmental stage (Immonen and Antila, 1998). Nevertheless, it is important to note that the measurements obtained for this parameter in each microspore developmental stage varied according to the genotype and the cultivation place.

\section{CONCLUSION}

Some morphological traits of a plant can be correlated with different developmental stages of the microspores, that can facilitate the collection of the tassels and the selection of adequate anthers to culture. Nevertheless, the place where the plants are cultivated can cause difficulty in the establishment of any correlation. The plants grown in the field presented little variation between the genotypes for the plant age and number of leaves. On the other hand, plants cultivated at growing chamber showed more variation in relation to these characteristics in the two genotypes. The anther length seemed to be the most reliable morphological measurement to identify the developmental stage of the microspore. However, the anther length must be chosen according to the genotype. The anther size that could be useful in one genotype might not be necessarily adequate for another one. The same was observed for the plant cultivation place.

\section{ACKNOWLEDGEMENTS}

This work was supported by CNPq (Conselho Nacional de Desenvolvimento Científico e Tecnológico, Brazil).

\section{RESUMO}

A utilização do milho (Zea mays) na cultura de anteras é limitada devido ao baixo número de genótipos com alto potencial androgenético. A obtenção de micrósporos no estádio de desenvolvimento apropriado no início da cultura é um dos fatores cruciais para o sucesso do processo androgenético. Em genótipos brasileiros de milho não existem estudos relatando a correlação entre características citológicas e parâmetros morfológicos. Neste estudo, parâmetros morfológicos foram avaliados e associados com estádios específicos da microsporogênese em dois genótipos brasileiros de milho os quais foram semeados em diferentes locais (campo e câmara de crescimento). Para ambos os genótipos, as plantas crescidas na câmara de crescimento apresentaram atraso no desenvolvimento. O comprimento da espigueta e a razão comprimento da antera/comprimento da espigueta não são bons parâmetros uma vez que podem ser muito influenciados pelo ambiente. O comprimento da antera foi o melhor parâmetro para indicar o estádio de desenvolvimento do micrósporo. Todavia, variações entre genótipos e ambiente foram detectadas.

\section{REFERENCES}

Afza, R.; Shen, M.; Zapata-Arias, J.; Xie, J.; Fundi, H. K.; Lee, K. S.; Bobadilla-Mucino, E. and Kodym, A. (2000), Effect of spikelet position on rice anther culture efficiency. Plant Science, 153 (2), 155-159.

Brasileiro, A. C. R.; Willadino, L.; Guerra, M.; Colaço, W.; Meunier, I. and Camara, T. R. (1999), Efeitos do estádio de desenvolvimento da antera e da radiação gama na formação de calos derivados de anteras de tomate. Scientia Agrícola, 56(4), 835-842.

Chang, M. T. and Neuffer, M. G. (1989), Maize microsporogenesis. Genome, 32, 232-244

Gresshoff, P. M. and Doy, C. H. (1972), Haploid Arabidopsis thaliana callus and plants from anther culture. Aust. J. Biol. Sci., 25, 259-264.

Immonen, S. and Anttila, H. (1998), Impact of microspore developmental stage on induction and plant regeneration in rye anther culture. Plant Science, 139(2), 213-222.

Jähne, A.and Lörz, H. (1995), Cereal microspore culture. Plant Science, 109(1), 1-12.

Kameya, T.and Hinata, K. (1970), Induction of haploid plants from pollen grains of Brassica. Japan Journal of Breeding, 20, 82-87.

$\mathrm{Ku}$, C.S.; Cheng, W.C.; Kuo, L.C.; Kuan, Y.L.; Na, H.P. and Huang, C.H. (1978), Induction factors and morpho-cytological characteristics of pollen-derived plants in maize (Zea mays). Paper presented at Symposium on Plant Tissue Culture, Peking.

Lauxen, M. S.; Kaltchuk-Santos, E.; Hu, C. H.; Callegari-Jacques, S. M. and Bodanese-Zanettini, M. H. (2003), Association between floral bud size and developmental stage in soybean microspores. Braz. arch. biol. technol, 46(4), 515-520. 
Murigneux, A.; Bentolila, B.; Hardy, T.; Baud, S.; Guitton, C.; Jullien, H.; Ben Tahar, S.; Freyssinet, G. and Beckert, M. (1994), Genotypic variation of quantitative trait loci controlling in vitro androgenesis in maize. Genome, 37, 970-976.

Peters, J. A.; Bobrowski, V. L. and Rosinha, G. M. S. (1999), Produção de haplóides e duplo-haplóides. In: Cultura de Tecidos e Transformação Genética de Plantas, ed. A C. Torres, L. S. Caldas and J. A Buso. EMBRAPA-SP/EMBRAPA-CN PH, Brasília, pp. 569-611.

Petrova, A.; De Ruijter, N. C. A.; Van Lammeren, A. A. M. and Schel, J. H. N. (1993), Structural observations during androgenetic microspore culture of the 4c1 genotype of Zea mays L. Euphytica, 65(1), 61-69.
Rodríguez, R. G.; Peña-Valdivia, C. B.; Ortíz, J. C.; Molina, J. D. G. and Madrigal, R. L. (1998), The improvement of maize (Zea mays L.) anthers tissue culture by the addition of free amino acids in the culture medium. Cereal Research Communications, 26(4), 357-365.

Wang, M.; Van Bergen, S. and Duijn, B. V. (2000), Insights into a key developmental switch and its importance for efficient plant breeding. Plant Physiology, 124, 523-530.

Received: January 20, 2006; Revised: March 12, 2007

Accepted: March 18, 2008 